\title{
Education in the Knowledge Society
}

\section{Education, Activism and Digital Technologies: A Systematic Review}

\section{Educación, activismo y tecnologías digitales: una revisión sistemática}

\author{
Nicolás Aguilar Forero ${ }^{\mathrm{a}}$, Gary Alberto Cifuentes Álvarez ${ }^{\mathrm{b}}$ \\ aFacultad de Educación, Universidad de los Andes, Bogotá, Colombia \\ https://orcid.org/0000-0002-9181-0281_nj.aguilar1902@uniandes.edu.co \\ bFacultad de Educación, Universidad de los Andes, Bogotá, Colombia \\ https://orcid.org/0000-0002-0778-0658_gcifuent@uniandes.edu.co
}

\section{ART I C LE IN F O}

\section{Key words:}

Education

Activism

Digital technologies

Political Practices

Thematic analysis

\begin{abstract}
A B S T R A C T
Although digital activism and mobilization around education is booming worldwide, few educational studies have addressed the relationship between education and activism mediated by digital technologies. This article explores how the scientific literature has conceptualized the relationship between education and activism mediated by digital technologies through a systematic review of international studies published between 1996 and 2016. The research uses thematic analysis to identify emergent patterns and relationships in the scientific literature. Thus, 392 articles were reviewed, and 40 were selected for a more detailed analysis. The findings show that it is necessary to problematize certain conceptual distinctions that some studies make (e.g., formal, non-formal, informal education). We propose a new typology of political practices, which transcend this type of distinctions present in the scientific literature. Conclusions address a necessary integration of a "practical turn" when analyzing the links between activism, digital technologies, and education since this approach allows one to challenge the binary distinctions and oppositions identified in the scientific production of knowledge.
\end{abstract}

R E S U M E N

Pocos estudios en el campo educativo se han preocupado por la relación entre educación y activismo mediado por tecnologías digitales. Sin embargo, dadas las crecientes oleadas de activismo y movilización en el mundo con diversas expresiones educativas, esta relación merece un análisis exhaustivo. El presente artículo indaga cómo la literatura científica ha conceptualizado la relación entre educación y activismo mediado por tecnologías digitales, a través de una revisión sistemática de estudios internacionales publicados entre 1996 y 2016. El enfoque metodológico de esta investigación se basó en un análisis temático, el cual permitió identificar patrones y relaciones emergentes en la literatura científica analizada. Se revisaron 392 artículos y se seleccionaron 40 para un análisis más detallado. Los resultados permiten sostener que, para entender los vínculos entre el activismo mediado por tecnologías digitales y la educación, es necesario problematizar ciertas distinciones conceptuales que hacen algunos estudios al referirse, por ejemplo, a la educación formal, no formal e informal. A partir de allí se propone una nueva taxonomía de prácticas políticas que permiten superar esta y otras distinciones presentes en la literatura científica. Se concluye que es necesario incorporar un "giro práctico" al momento de analizar los vínculos entre activismo, tecnologías digitales y educación, ya que este enfoque permite desafiar las distinciones y oposiciones binarias identificadas en la producción de conocimiento analizada.

\section{Introduction}

The use and appropriation of digital technologies has modified the political practices of social movements, organizations and collectives in the public sphere of different countries in recent years. These uses have also affec- 
ted the relationship between activism and education, leading to new possibilities and experiences. The history of activism in the contemporary world has been linked to the classical movements. In the 1960s, for example, the ethos of social movements was especially linked to the labor movement, student movements, and in Latin America, to peasant and political-revolutionary movements. Activism at that time was associated with the transformation of social structures, and these processes were conceived of as liberating.

Later on, in the 1980s, new groups, actors, and collectives emerged on the public stage decentralizing the paradigm of the revolution. This drew attention to various social contradictions and issues of dispute that went beyond class or economic conflicts (Garcés, 2010). Human rights, feminist, urban, ethnic, sexual, juvenile movements began to proliferate and gain momentum due to multiple forms of oppression (mainly state oppression) that turned into various types of resistance. As Melucci (1999) and Delgado, Ocampo and Robledo (2008) point out, these emergent expressions of social activism have been linked to certain characteristics: 1) they move through more informal political spaces (usually outside parties and unions); 2) they are organized on the basis of emotional or solidarity bonds; and 3) they act on specific demands linked to identity and symbolic-cultural elements beyond strategic, economic, or material issues.

Since the 1990s, and especially in the first two decades of this century, the use of digital technologies by social movements has opened up new frontiers. The waves of social upheaval that have recently shaken the world (e.g. those of 2006, 2011 and 2013) drew attention due to their new organizing mechanisms and results; they rapidly coordination actors and activities led to mass occupations of major cities such as Cairo, Tunisia, Athens, Madrid, Barcelona, New York, Mexico City, Santiago de Chile and Bogotá. They brought thousands of people together, and they shocked the public by incorporating forms of protest linked to art and culture (carnivals, body-art, concerts, flash mobs, camping, performances, etc.), having a strong youth presence, using non-hierarchical forms of organization, and experimenting with communicative and educational practices far removed from traditional approaches and structures.

Though many authors have contributed significantly to the literature on the changes in the types of organization, mobilization and political action produced by new technologies, a need to deepen the discussion on the political practices of contemporary activism and to understand the relationship between activism mediated by digital technologies and education still exists. This article seeks to contribute to that discussion and understanding by answering the following research questions:

- How has the relationship between education and activism mediated by digital technologies been traditionally studied?

- What terms and categories have been proposed?

- What is the geographical distribution of the studies?

- What sort of patterns and political practices emerge from empirical studies on this relationship?

To address those questions, this work is divided in four sections. The first section describes some theoretical background on activism and its links with digital technologies and education. The second section describes the methodological approach of this study: a thematic analysis of the literature. The third part recounts some political practices of contemporary activism around the world in recent years. In this section, we problematize the categories of formal, non-formal and informal education used to describe activism mediated by digital technologies. The last section makes a claim for a practical turn to transcend traditional distinctions, boundaries and hierarchies in the study of activism mediated by digital technologies and education.

\section{Activism and its relationship with the field of education}

Activism has been defined as a form of political and cultural intervention practiced both online and offline at different scales (local and global) and durations (long, medium, or short). It can incorporate technological tools and the Internet (Boumlik \& Schwartz, 2016; Vivitsou \& Viitanen, 2015). This conceptualization is based on a long history of knowledge production around collective action and social movements. Among the most significant contributions are the following approaches:

- Theory of resource mobilization. Focused on internal resources from social movements and their capacity to establish alliances and achieve strategic goals.

- $\quad$ Theory of political processes. Based on the key concept of political opportunity structure; this theory is related to the interactions between collective actions and the opening or closing of political systems (Tilly, 1995; Tarrow, 1997). 
- Identitarian paradigm. Oriented to the analysis of emergent collective identities that encompass causes related to sexuality, gender, generation, ethnicity, religion, territory, among others (Touraine, 1987, 1997; Melucci, 1999).

- Other approaches analyze and combine some of the previous elements as a part of the emergence and development of New Social Movements -NSM- (since the 1980s). These approaches take into account factors such as the structure of political opportunities and the constraints that social movements have to face, the formal and informal ways of organization and the collective process of interpretation and social construction that mediate between opportunity and action (McAdam, McCarthy, \& Zald, 1999).

Nevertheless, in the recent years the use and appropriation of digital technologies has changed the theoretical approaches to activism. Arab Spring, the Indignant Movement in Spain, Occupy Wall Street and the student movements in Latin America, owe their success to the widespread appropriation by activists of platforms such as Facebook, Twitter and YouTube. The most recent activism experiences that have politicized cyberspace can be distinguished from the NSM of the 1980s. Different authors have embraced new approaches and incorporated new concepts in their work like: crowd-based political action (Hardt \& Negri, 2004); newest social movements (Feixa, Juris, \& Pereira, 2012); networks of indignation and hope (Castells, 2012) and networked protest (Tufekci, 2017).

The newest social movements usually are organized around plural motivations linked to diverse sources of indignation: imposed educational reforms (Bekkers et al., 2011); sexual violence; discriminatory policies and the need for a better sex education policy (LaRiviere et al., 2012; Linder et al., 2010; Shayne, 2008); abduction and violation of the right of women to formal education (Chiluwa \& Ifukor, 2015); job insecurity (Biddix \& Park, 2008); defense of high quality public education (Valenzuela, 2013; Theocharis, 2012; Heron-Hruby \& LandonHays, 2014; Fullam, 2017); genocide or extreme violence (Biddix, 2010); environmental damage and animal abuse (Pearson et al., 2016; Weeks, 1999), to name a few.

Despite the important contributions of such approaches to the analysis of contemporary activism, little attention has been paid to how political practices relate to educational ones. However, certain studies have shown how some movements, like feminist organizations, promote opportunities and spaces for non-formal learning (workshops, short courses) and informal (day-to-day) learning using new digital media and technologies. Through these spaces, movements offer mentoring services or support to women who are victims of all kinds of violence, including sexual abuse (Irving \& English 2011). In the same way, environmental organizations promote education on sustainability through videos and social networks. The videos circulated through YouTube show the impact of deforestation, or other types of environmental damage, in order to promote awareness, learning, responsible consumption and fundraising for environmental organizations (Pearson et al., 2016).

As Biddix (2010) explains, although certain movements or organizations intentionally promote educational activities, most of the knowledge gained is derived from daily, 'informal' interactions. In this regard, interactive media and platforms offer constant contextual and relational learning. Learning does not only happen as knowledge acquisition; in fact, activism mediated by digital technologies promotes relational learning that emerges from social interactions both online and offline. The various forms of learning are typified below:

- Knowledge: learning emerges due to study of topics of interest received in different formats (text, audio, video), which encourage the construction of informed and critical opinions.

- Skills: skills are acquired to a) politically appropriate digital technologies and various Internet tools; b) research, debate and participate; c) generate teamwork and coordination of collective actions and leadership.

- Attitudes: attitudes acquired which are favorable to the respect of online and offline interaction rules, and to the development of a sense of responsibility and commitment to public life (Biddix, 2010).

As can be seen, processes of activism mediated by digital technologies are themselves educational as they involve diverse types of learning. These types of learning are primarily aimed at people who participate directly in activism but can reach more broadly when social movements intentionally seek this societal education. Through dissemination of different educational content on digital platforms, or through educational spaces (workshops, courses, popular education experiences and even universities), learning is created by social movements and powered by digital technologies. Of course, just as activism mediated by digital technologies is inherently educational, education cannot be conceived of only as part or dimension of the processes of resistance and social activism. As has been widely discussed, education is in itself a form of activism or, at least, a political exercise: "besides an act of knowledge, education is also and always a political act" (Freire, 2014, p. 34). 
To deepen the discussion of how scientific literature addresses this relationship between activism mediated by digital technologies and education, in the next sections we present the methodological proposal of the study and the results.

\section{Method}

To better understand how scientific literature builds knowledge on the relationship between activism mediated by digital technologies and education, a thematic analysis was conducted. This method allows for the identification and analysis of patterns in the sources analyzed (Braun \& Clarke, 2006). Below we present the inclusion criteria and the three phases of the systematic review.

\subsection{Inclusion criteria}

More than 10 databases from different areas including Scopus, Web of Science, JSTOR, Wiley Online Library, ProQuest, and Ebsco Host, were reviewed. The bank of documents was included work from a period of twenty years: from 1996 to 2016 . We selected this period due to amount of work produced on the relationship between education and activism mediated by digital technologies in this time span. The inclusion criteria used were as follows:

- Empirical studies with quantitative, qualitative or mixed methods data.

- Peer reviewed articles (to ensure quality and reliability) published between 1996 and 2016.

- Papers where the words education, digital technologies and activism (or equivalent terms such as social media activism) appear together in the title, abstract or keywords.

\subsection{Procedure}

Phase one: familiarization with sources. The exploration was focused on English and Spanish as these languages had greatest quantity of knowledge production on the topic worldwide. After including the search filters (activism, digital technologies and education) 392 documents were identified. In the first phase titles, summaries and keywords of all the 392 sources were revised to confirm the inclusion criteria and become familiar with the sources and the general topic of the study.

Phase two: categorization and coding. As noted by some authors (Osses, Sánchez, \& Ibáñez, 2006; Braun \& Clarke, 2006), while categorization allows us to classify units that are conceptually addressed by the same topic, coding makes it possible to organize data into meaningful and easily identifiable groups. Hence, using a co-occurrence approach, we grouped and numbered certain words that appeared together in the same paragraph, including titles, abstracts and keyword of all the texts. Then, we tried to identify whether similar words and phrases expressed the same idea (Auerbach \& Silverstein, 2003). In this stage, it was found that activism, digital technologies and education were not the most relevant co-occurring words; in fact, many other terms emerged from the coding stage.

Taking this fact into account, the emergent terms were numbered and categorized. We created seven categories that were the most significant according to their frequency in the titles, abstracts and keywords of the initial corpus of texts. The seven categories that appear linked to education were social media activism, cyberactivism, Internet activism, online activism, digital activism, cyberfeminism and cybercitizenship.

From this review, we selected 40 documents that were linked to the main research questions and inclusion criteria. Taking into consideration the previous categories and codes, the most relevant information from these 40 documents was summarized and analyzed in tables based on the following items or questions: 1 ) author and publication date; 2) country where research was conducted; 3) journal/publisher; 4) materials and methods; 5) How is activism mediated by digital technologies understood in the different documents? 5) How is education understood and what place does it have in each text? These items and question made it possible to do a transversal, systematic analysis of how the literature approaches certain political terms, concepts and practices.

Phase three: identification of concepts, patterns and emerging relationships. The most important results of this review were recorded in seven documents based on the seven categories identified. Finally, an analytical matrix was created to facilitate comparison between the seven documents and identification of emerging 
relationships, concepts and patterns in all the information. During the three phases, the two authors discussed advances, results and reached consensus jointly about their interpretations.

\subsection{Limitations of the study}

While our inclusion criteria consider various important factors, they do have some limitations. For example, by selecting certain databases and peer review articles published between 1996 and 2016, the most recent bibliography is excluded from the analysis. In addition, our selection does not consider contributions made to the field from books, theses or other research circulated outside of indexed journals or databases like Scopus or Web of Science. Similarly, our analysis only considered production in two languages (English and Spanish), which excludes academic production in languages such as French or Portuguese, in which there have also been significant contributions to the topic of study. Finally, the decision not to use specialized software for the analysis could have effects on the final selection of 40 texts. Since the text selection was based on our questions, comparisons and matrices developed by us, and was heavily dependent on our interpretations, this could influence certain findings.

\section{Results and analysis}

\subsection{Activism mediated by digital technologies and education: Conceptualizations}

In the first stage of analysis, graphs were used to visualize trends obtained from databases. For instance, in Scopus, we did not find any mention of the relationship between activism, digital technologies and education; instead, education was related to other keywords such as social media activism (115 texts), cyberactivism (52), Internet activism (47), online activism (42), digital activism (28) or cyberfeminism (3). The following graphs show the association of terms (in this case social media activism and education) which yielded the greater amount of scientific literature, taking into account the year of publication (Figure 1) and the geographical context of the study (Figure 2).

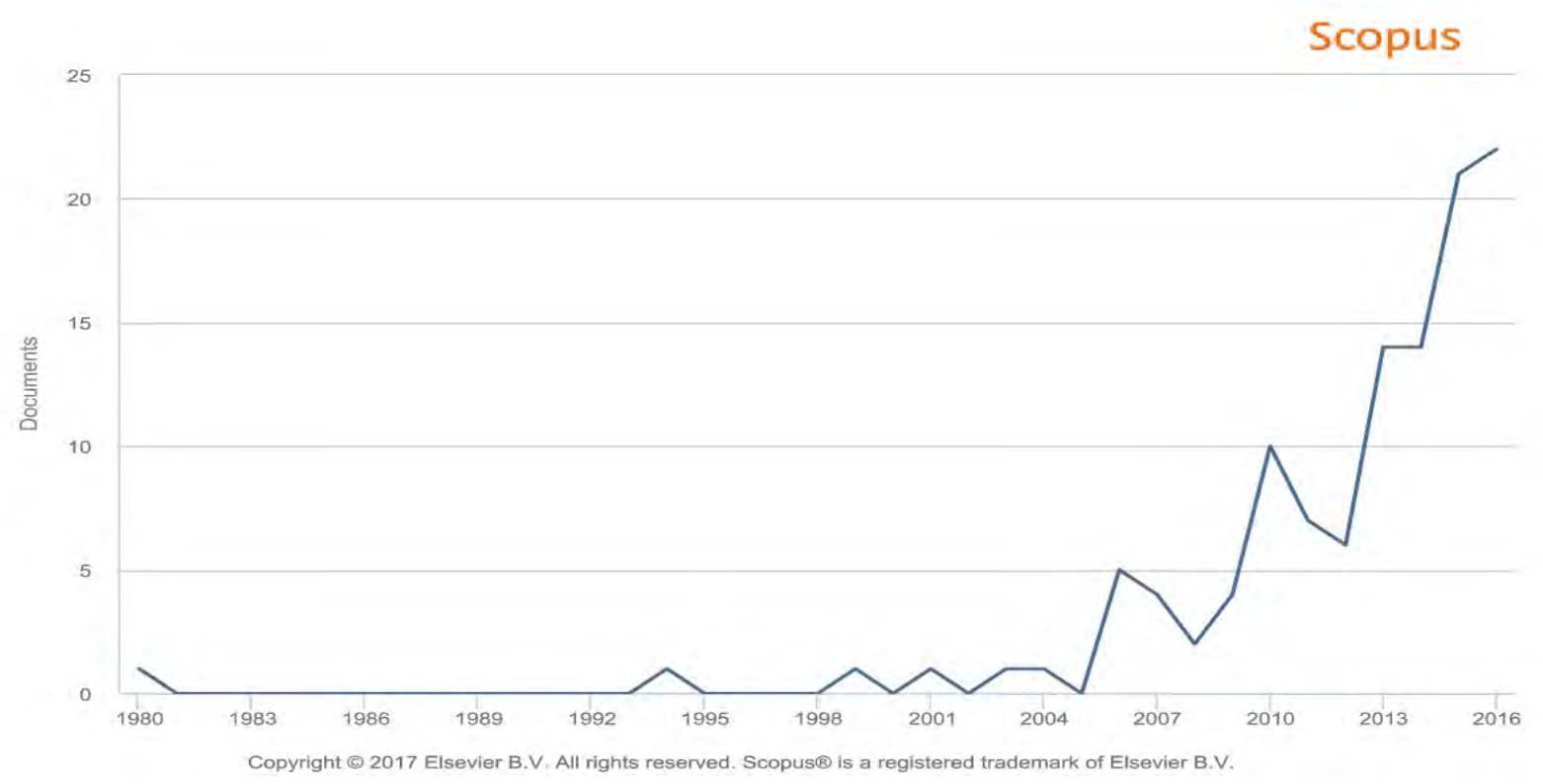

Figure 1. Social media activism and education (115 sources). Association according to year published 


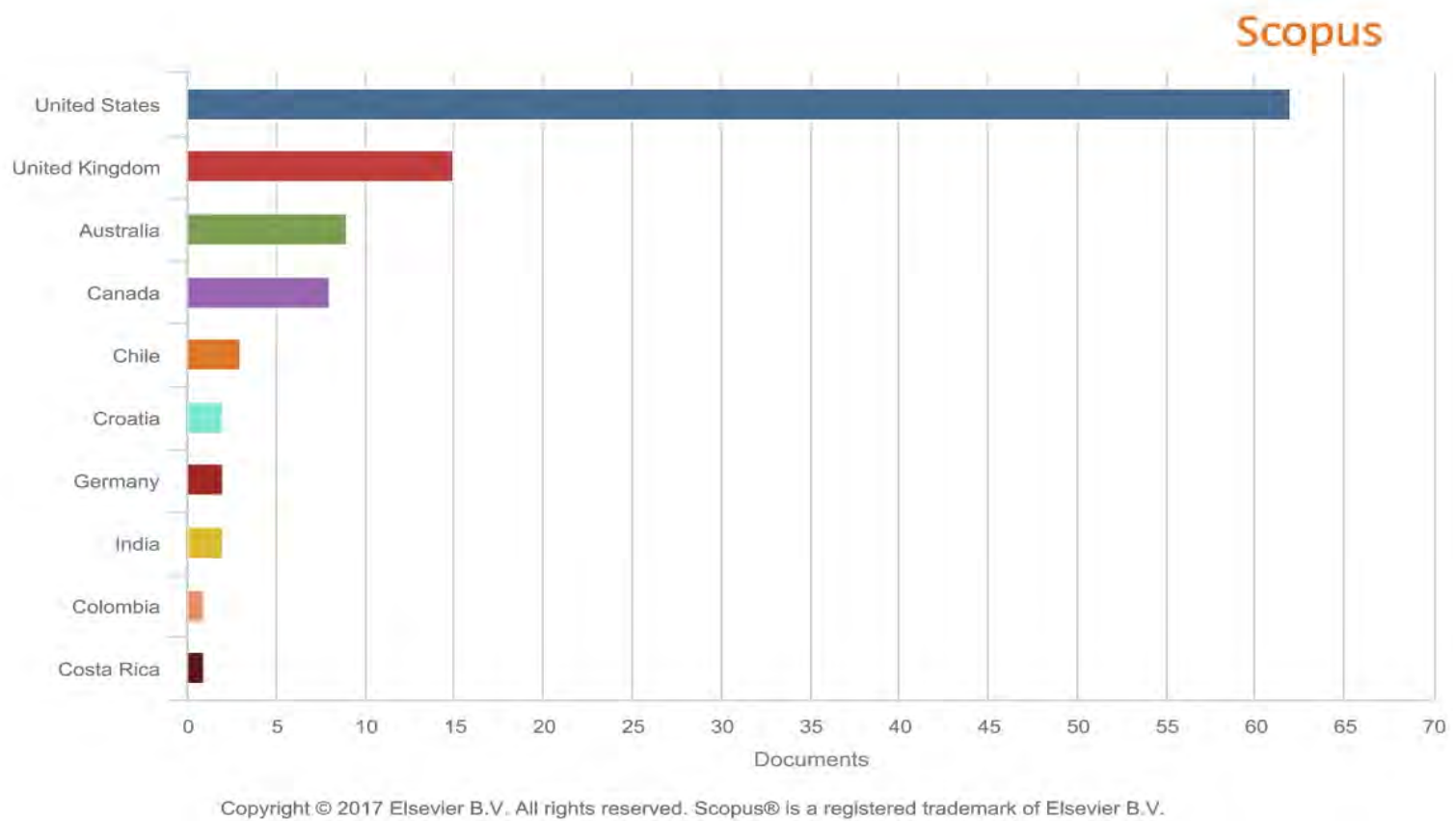

Figure 2. Social media activism and education (115 sources). Association according to the geographical ascription of the texts

As can be seen in the graphs, the production of knowledge about activism mediated by digital technologies (in this case, under the category of social media activism specifically in Scopus) and its link with education, began to increase in 2010, particularly in the United States, the United Kingdom, Canada and Australia. In contrast, the literature from Spain and Latin America is much less prevalent; it primarily comes from Chile according to the geographical context of the studies. In other databases, such as Web of Science, we found a similar situation: most of the production emerged between 2011 and 2016 from countries such as the United States, Australia, England and Canada. In this case, however, there is less production from Latin American countries; for instance, neither Colombia nor Costa Rica appear in the results:

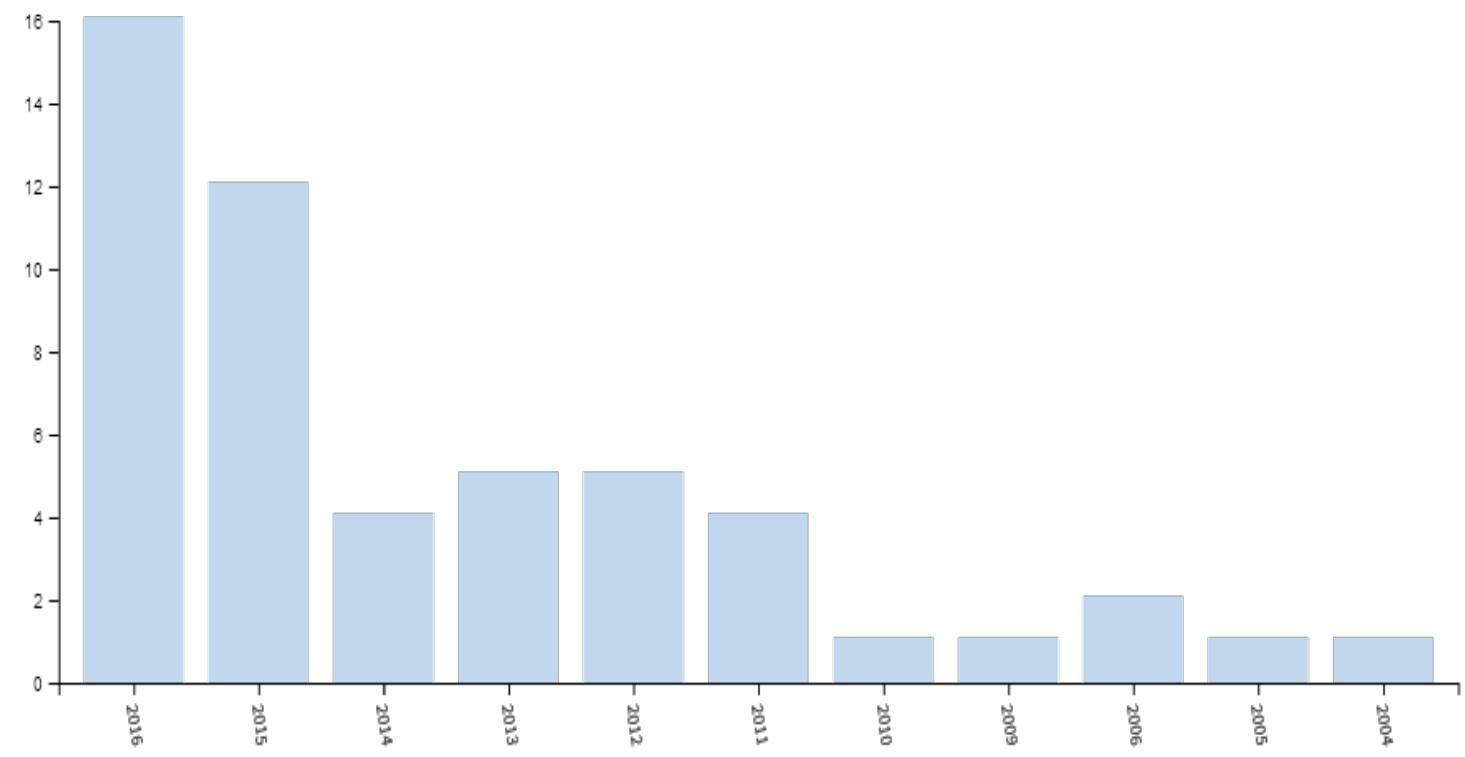

Figure 3. Social media activism and education (52 sources). Association according to year published. Source: Web of Science 


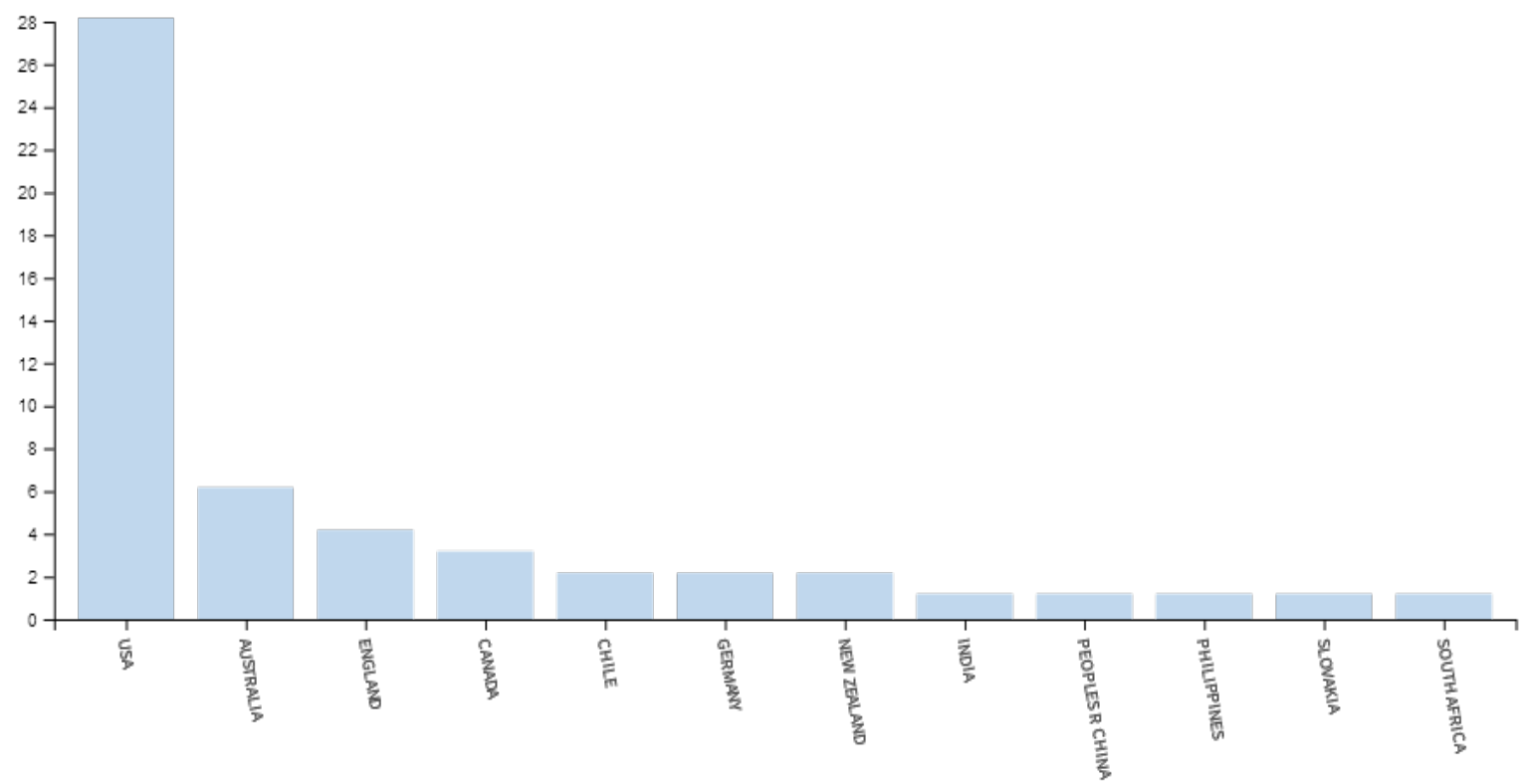

Figure 4. Social media activism and education (52 sources). Association according to the geographical ascription of the texts. Source: Web of Science

It is important to draw attention to certain elements that emerged from the literature review. The first one reveals that in most of the literature analyzed, the concepts and the distinctions between them are not rigorously defined. In some cases, the categories are named but not developed, and in other cases, the concepts whose similarities or differences would be worth analyzing are used as equivalents (e.g., Linder et al., 2010; Shayne \& Shayne, 2008, Heron-Hruby \& Landon-Hays, 2014; Khoury-Machool, 2007). Secondly, for some authors, education is merely a context in which activism or technological appropriation occurs. One could say that education is represented as an 'institutional container' for activism. Examples of this are studies on young activists in schools who display interest and indignation about topics like environment, animal protection, sexual diversity and human rights, using social media (González-Lizarraga, Becerra-Traver, \& Yanez-Díaz, 2016; Linder et al., 2010; Fullam, 2017). In this case, education is just a 'context' or a 'condition' because the activists are 'students'.

Likewise, in much of literature, education is conceived of in terms of the traditional categories of formal, non-formal and informal education. In several cases, what is criticized is the formal educational environment itself, though the 'formal' category is taking for granted (Bekkers et al., 2011; Valenzuela, 2013; Heron-Hruby \& Landon-Hays, 2014; Theocharis, 2012). In some other cases 'formal' refers to concrete practices in which young people are sensitized or empowered through curricular or didactic strategies (Mills et al., 2011; Glenn, 2015; Vivitsou \& Viitanen, 2015). On the other hand, in several texts, emphasis is on non-formal education, understood as the education which is enacted on extracurricular spaces such as social organizations, social movements or NGO (e.g. Weeks, 1999; Enguix, 2016; Share \& Shayne, 2008).

Beyond the semantic discussion, the thematic analysis reveals that in the empirical studies, the relationship between activism mediated by digital technologies and education is based on concrete political practices that involve different levels of participation. In what follows we propose a new typology of political practices identified in the scientific literature. We also problematize some categories frequently used to understand the complex connection between activism mediated by digital technologies and education.

\section{The political practices of contemporary activism: Beyond distinctions}

\subsection{Critical and active media consumption}

This political practice consists of following critical content or groups working on political, sociocultural or environmental issues online. Exposure to this type of content, in addition to promoting learning and awareness, can lead to action. For example, it can be manifested in actions like expressing support for certain topics of interest 
by modifying the personal profile photo in social networks or by posting messages of solidarity. It can be manifested in other actions likes signing letters and virtual petitions in order to demonstrate indignation, making demands or generating pressure to promote changes and influence national political and media agendas (Theocharis, 2012; Share \& Shayne, 2008; Bekkers et al., 2011).

As Juris (2008) explains through his ethnographic analysis of the anti-globalization movement, people involved in newest social movements consume critical information and promote alternative interpretations of certain events through different media and mediations. In contrast to corporate media, which often represents the political, economic and socio-cultural realities and interests of their owners, the contemporary activists create counterhegemonic spaces (counter-spaces) in which structural issues, ususally marginalized in mainstream media, can be discussed. Therefore, activism mediated by digital technologies makes it possible to question dominant media narratives, generate spaces of resistance and visualize the stories or voices of marginalized communities (Linder et al., 2010; Pearson et al., 2016).

Some scholars have recently claimed that these characteristics supersede classical distinctions between consumption of mass media and the production of content (Gibbons, 2017). As Urresti (2008) suggests, youth are no longer consumers of information, but 'prosumers' (as coined by Alvin Toffler). Prosumers refers to a hybrid between a consumer and a content producer. Their practices include those that may be construed as similar to a traditional consumer but with a critical eye: passive regarding production but active in reception. But their practices also include those of the autonomous producer who consumes what he or she produces (Urresti, 2008).

Indeed, as is expressed in the literature, organizations, networks and newest social movements have use their web pages and other platforms of cyberspace not only to protest and consume critical information, but also to learn and educate others by offering training, support or counseling (Enguix, 2016). Activists in cyberspace have several resources available, like those of the NGO Advocates For Youth (a north American organization supporting intergenerational activism). These resources include online tools to learn about production/ circulation of virtual petitions, creation of community forums, effective use of social media and lobbying tactics with decision-makers on issues of interest (Shayne \& Shayne, 2008).

Nevertheless, activism mediated by digital technologies implies different levels of participation, beginning with critical, active consumption (which goes beyond simply consuming) and increasingly reaching a productive level as they politicize (without becoming production only). In the following section we describe a second set of practices that complement and overlap with the critical and active media consumption.

\subsection{Searching for and circulating information}

Along with critical and active media consumption is the practice of searching for and circulating information or content. The search implies a willingness to research, learn and think critically, which of course transcends mere reading or 'consumption' of information. The circulation of content, on the other hand, is based on massive or selective diffusion of reflective documents, public denunciations, campaigns, opinion articles, all kinds of 'counter-informative' content and announcements about past, present or future collective actions (Valenzuela, 2013; Glenn 2015; Khoury-Machool, 2007).

As we have identified in some of the studies reviewed, in this type of practices formal, non-formal and informal education enter into a complementary or articulated relationship, which invites us to question the very distinction between these educational domains. One instance of this is illustrated in what happened after the political changes with Arab Spring in Tunisia. After technology and Internet tools were used rebelliously to circulate information and to encourage the revolts to overthrow Ben Alli, the same tools were then used to foster awareness, democratization and education. This was achieved through the political-communicative practices of certain NGOs such as Al Bawsala, which promoted the empowerment of citizens through popular education activities and the circulation of information through their website ${ }^{1}$. Al Bawsala also created spaces for debate between politicians and citizens and fostered a new political culture linked to the monitoring of legislative and governance practices to ensure the transparency of the new regime in that country (Boumlik \& Schwartz, 2016).

1. Al Bawsala is a non-profit NGO established under Tunisian law. It has three objectives: 1) to reposition citizens at the core of political action by offering them the means to stay updated with their elected representatives and by providing them ways to defend their fundamental rights; 2) to build relationships with elected representatives and decision-makers in order to work towards the establishment of good governance practices and political ethics; 3 ) to participate in defending the concepts of social progress and citizen empowerment (more information available in the website: https://www.albawsala.com/en/presentation). 
In this case, the educational process moves from the 'informal' to the 'non-formal' with no clear boundaries between these domains.

Similarly, in relation to the critical and active consumption of content, searching for and circulating information implies a higher level of politization, usually adressing colective actions. This in turn relates to the third set of practices identified in the thematic analysis.

\subsection{Coordination of actions}

Coordination of actions is related to practices in which collective actions, such as protests, mobilizations, campaigns, mass events, meetings, forums, seminars, educational activities and so on, are organized or promoted. Action coordination, enhanced by the use of digital technologies, implies not only reaching agreements on the logistical elements, but also sharing points of view, discussing ideas, defending opinions and making decisions. This last element, as Biddix (2010) explains, may be simpler in the case of small organizations since large organizations require face-to-face meetings, not only internet interactions.

In any case, the coordination of actions within educational processes transcends the traditional distinctions between formal, non-formal and informal as it takes place in parallel settings and with different levels of formality. We can see this in the case of studies on the revolts and encampments of 15M in Spain (Fernández-Planells, 2013) or the Occupy Wall Street movement in the United States (Juris, 2012). Despite that the collective actions on Internet at the beginning motivated mobilizations and awareness in an 'informal' and expanded manner, various commissions began to emerge when the occupations in the squares of the most important cities in both countries took place. Education commissions stood out among the most important and were in charge of promoting educational spaces with higher levels of formality. Likewise, when the occupations and the encampments dissipated, it was decided to channel the disruptive energies towards decentralized, organizational, and educational processes online or in different neighborhoods with diverse communities.

The coordination of actions cannot be classified according to traditional distinctions like those online/ offline given that such coordination is enacted simultaneously in hybrid and interdependent settings. In fact, this is another feature of contemporary activism; it circulates through interstitial spaces where online activity does not replace, but rather complements and reinforces offline political participation (Metzger et al., 2015). For this reason, the very distinction between online and offline in general, or between online activism and offline activism in particular, should not be maintained. Instead of two separate worlds of social activism, these are hybrid, convergent deployments with multiple intersections. This activism relies both on streets and on the Internet for its construction and occupation of public space (Linder et al., 2010; Valenzuela, 2013). However, although one may think the coordination of collective actions online/offline implies a very high level of participation and politicization, the content production, which is discussed below, challenges this notion.

\subsection{Content production}

With this practice, activists go from active consumption to active production by creating, modifying and editing content such as photos, videos, and texts. In some cases, platforms such as Google docs enable the creation of documents that movements or collectives build collaboratively. Other content may come in the form of images or videos to publicize actions carried out or to denounce acts of repression. For example, recently young people have responded to the attacks carried out by public forces on protesters in North Africa, Spain, the United States or Latin America by recording what happened and uploading the videos to the web, often anonymously and with little editing (Peña, Rodríguez, \& Sáez 2016). Due to the communicative power of the videos, thousands of people have joined the protests after feeling empathy and solidarity with the demonstrators.

In the case of education, content production as a means of activism mediated by digital technologies also blurs the distinction between formal, non-formal and informal domains. For instance, in some of the texts revised, the links and transitions from the 'formal' to the 'non-formal' and 'informal' are also noticable in the political practices of contemporary activism. In Chile, for example, many young people used audiovisual production abilities they had learned at school ('formal') in spaces of mobilization ('informal'). In fact, several leaders and members of the Chilean student movement who in 2011 demanded a free, quality public education by occupying educational institutions and mobilizing in mass, used what they learned at school in regards to the use of digital technologies along with audiovisual production to create 'non-formal' learning experiences. As a result of what was learned at school, the young people relied on their technical knowledge and skills in the use of digital 
technologies and the Internet to produce and massively circulate creative videos that had a strong emotional impact on other young people (Peña, Rodríguez, \& Sáez, 2016).

Another example is the work of Khoury-Machool (2007) which analyzes the case of Palestine, where NGOs like the Palestinian Youth Association for Leadership and Rights Activation (PYALARA) and universities like Bit Zeit University of Ramallah, created several educational initiatives for the appropriation of Information and Communication Technologies (ICT) that fostered the creation of virtual radios, blogs and web pages by students. This appropriation generated a new political culture because young people began to report on the situations of their neighborhoods, families, teachers, schools and so forth, through the dissemination of photographs, texts and video clips on the Internet. This provided a great opportunity for young Palestinians in the occupied territories to express themselves, to make their stories visible, to maintain communication with peers, friends and family in the diaspora and to establish transnational communities of interaction and collaboration. Thus, a causal relationship was established between 'formal' educational processes and the appropriation of ICTs to generate 'non-formal' and 'informal' initiatives for training and communication.

\subsection{Hacker practices}

Even though the aforementioned practices imply varying levels of participation and relations with cyberspace, hacker practices could be understood as the more 'active' o 'radical' ones. These practices are organized by activists savvy in coding and programming languages. Hackers produce or develop technologies and platforms and move through independent networks and free software. As Rueda (2004) points out, hackers aim at subverting the control and power patterns behind authoritarian and undemocratic technological designs and transforming what circulates in virtual environments for the public good. This form of activism and resistance in the network is distinct from cracking, the practice of breaking into security systems. The world of hackers is related to the construction of a radical digital citizenship, not to committing crimes or to breaking the law (Emejulu \& Mcgregor, 2017). Hacking can initiate collective and emancipatory technological actions through alternative communicative infrastructures such as independent information networks, non-commercial Internet providers and freeware platforms. This promotes dialogue, organization and mobilization outside the corporate media infrastructure.

Although one could consider the practices performed by hackers to be successful (for instance blocking government or corporative organizations websites) these practices have also been criticized because they have no 'real effects'; to some they are just slacktivism, a hybrid of slacking and activism. Slacktivism, from Glenn's (2015) perspective, consists of a form of 'awareness' that is not 'real activism' because it implies little time, minimal effort and no participation in mobilizations or concrete actions 'outside of the web'. These are practices through which one can be part of a group or webpage, read or share information on social issues, sign virtual petitions, 'like' certain content or participate in virtual boycotts without concrete contributions to the solution of social problems. Along the same lines, LaRiviere et al. (2012) states that Internet activism promotes low-commitment collective action (e.g. simply contributing 'clicks' to support the cause) and it prevents further recognition of complexities and commitments to the situations being protested.

However, some authors have started to remark on this problematic distinction between activism and slacktivism (Chiluwa \& Ifukor, 2015) since it reduces highly complex practices to opposing, hierarchical categories. In fact, while certain practices imply levels of participation and involvement that can be associated with 'low commitment', this does not necessarily mean that they cannot be translated or overlapped with other types of higher intensity activities that have long-term effects. As Knibbs (2013) points out, concrete practices such as signing a virtual petition or sharing supportive messages can have considerable effects when carried out by millions of people. Since different objectives go hand in hand with different actions, online practices, as trivial as they may seem, can have a great potential to achieve certain purposes, such as drawing public attention or persuading and generating pressure on specific issues. Similarly, it can be argued that people who are active in promoting or supporting causes on the Internet may be more likely to make donations, volunteer or engage in off-the-web activities (Metzger et al., 2015; Linder et al., 2010). In this sense, instead of understanding slacktivism as activism that is 'not real', 'false', or 'lazy', what we have are complex forms of activism that involve varying levels of participation and operate in the interstices between online and offline. 


\section{Conclusions}

Beyond the different and sometimes less rigorous ways of naming the relationship between activism mediated by digital technologies and education, the literature review revealed a broad set of political practices which involve different levels of participation: critical and active media consumption, searching for and circulating information, coordination of actions, content production, hacker practices. Likewise, in the different texts, activism mediated by digital technologies (or this concept referred to with different terms) is associated with various forms of technological appropriation that have diverse practices and purposes: raising awareness, protesting or defending certain causes of interest, promoting social mobilization, creating new forms of citizen participation, generating local, national and global collaboration networks, and strengthening solidarity and a sense of community (Pearson et al., 2016; Linder et al., 2010; Khoury-Machool, 2007; Theocharis, 2012; Peña, Rodríguez, \& Sáez 2016; Enguix, 2016; González-Lizarraga, Becerra-Traver, \& Yanez-Díaz, 2016; Vivitsou \& Viitanen, 2015; Weeks, 1999).

However, it is necessary to emphasize that in part of the literature analyzed, it is meaningless to speak of a clear division between 'formal', 'non-formal' and 'informal' educational domains. Additionally, in several cases already described, it is noticeable that some other distinctions are problematic: consumption/production, online/offline and activism/slacktivism. That is the reason why, based on the thematic analysis, we have identified and proposed a new typology of political practices, which transcend these dualisms, hierarchies, or naturalized categories present in certain studies. Taking into account the results of the thematic analysis, we also argue for a "practical turn" in the study of the relationship between activism mediated by digital technologies and education. The practical turn in social theory allows us to challenge taken-for-granted distinctions (technology/ society; online/offline; real/virtual; outside/inside) and pre-established categories such as formal, non-formal an informal education. Conversely, the practical turn focuses on the field of practices and relational dynamics, which are open to creative and disruptive enactments (Schatzki, 2001; Bolldén, 2016; Knorr-Cetina, 2001). To this extent, if new empirical studies make that practical turn, it could be possible to deepen de discussion about the typology of political practices proposed in the present article, instead of circulating traditional categories or oppositions as several scholars still do.

After this research, certain questions also arise: Can the diversity of political-educational practices of young people be reduced to the typology proposed in this article? What new political expressions may be emerging beyond what can be traced through investigative, analytical and conceptual procedures? What other distinctions in the academic literature can be overcome through the political practices of emerging activism? As some studies have pointed out, digital technologies have moved citizen struggles to the field of online/offline environments, breaking, among others, public/private, collective/individual or national/international distinctions (Suaza, 2013). This leads us to insist on the need for new studies and approaches that follow the practices and transcend the taken-for-granted distinctions or categories.

Likewise, we believe this approach could be useful to face certain challenges of the knowledge production on the field. For example, it is important to point out, as Emejulu \& Mcgregor (2017) do, that the analysis of processes of social revolt cannot be reduced to a romantic and naïve reading associated with horizontal relations, leaderless movements, and supposedly democratic mechanisms. Of course, activism implies power relations, conflicts and even hierarchies. As Biddix's (2010) study illustrates, though certain protests are spontaneous and horizontal in principle as they evolve, clear and defined leadership begins to emerge.

On the other hand, when avoiding an idealization of disruption experiences and resistance, one must also avoid embracing definitions of them that deny or minimize their potential. For this reason, it is problematic to associate certain actions with labels like 'light', 'lazy', 'low commitment' or 'outside real activism'. Behind these labels, there is a certain 'purism or essentialism' that aims to limit activism to presence on the streets and to inherited forms of politics resistance (e.g. marches, demonstrations, mobilizations, etc.). Beyond the distinction between activism and slacktivism, political practices with diverse horizons appear on a daily basis. This activism is not exclusively an online activity that scarcely affects 'real life', nor is it exclusively offline activism that marginally or instrumentally uses the technologies and the Internet for its purposes. On the contrary, digital technologies create a networked public sphere as well as networked movements that are not 'online-only' or even 'online-primarily'; these are 'a complex interaction of publics, online and offline, all intertwined, multiple, connected' (Tufecki, 2017, p. 6).

In conclusion, we claim for a practical turn as a necessary alternative to help erase traditional distinctions, boundaries and pre-established hierarchies in the study of the relationship between activism mediated by digital technologies and education. Activism in the contemporary world problematizes the distinction between formal, non-formal and informal education since its political practices express complex interactions between these 
three domains. The political actions of groups, networks or newest social movements are inherently educational, and they can hardly be reduced to concepts, distinctions or traditional conceptions of policy and citizenship. Education, on the other hand, is inherently political and it cannot be reduced to pre-established models or pedagogical theories; hence, social activism must be understood according to its specificities, practices and deployments in each context or experience of education and disruption. As a result, previous and naturalized categories, still present in the contemporary knowledge production, must be revisited in order to understand the present and imagine the future.

\section{References}

Auerbach, C. F., \& Silverstein, L. B. (2003). Qualitative Data. An Introduction to Coding and Analysis. New York and London: New York University Press

Bekkers, V., Beunders, H., Edwards, A., \& Moody, R. (2011). New Media, Micromobilization, and Political Agenda Setting: Crossover Effects in Political Mobilization and Media Usage. The Information Society, 27, $209-219$. doi:https://doi.org/10.1080/01972243.2011.583812

Biddix, J. P. (2010). Technology Uses in Campus Activism Form 2000 to 2008: Implictions for Civic Learning. Journal of College Student Development, 51(6), 679-693. doi:https://doi.org/10.1353/csd.2010.0019

Biddix, J. P. \& Park, H W. (2008). Online Networks of Student Protest: the Case of the Living Wage Campaign. New Media and Society, 10(6), 871-89. doi:https://doi.org/10.1177/1461444808096249

Bolldén, K. (2016). The emergence of online teaching practices: a socio-material analysis. Learning, Media and Technology, 41(3), 444-462. doi:https://doi.org/10.1080/17439884.2015.1044536

Boumlik, H., \& Schwartz, J. (2016). Conscientization and Third Space: A Case Study of Tunisian Activism. Adult Education Quarterly, 66(4), 319-335. doi:https://doi.org/10.1177/0741713616652475

Braun, V., \& Clarke, V. (2006). Using thematic analysis in psychology. Qualitative research in psychology, 3, 77-101. doi:https://doi.org/10.1191/1478088706qp063oa

Castells, M. (2012). Redes de indignación y esperanza. Madrid: Alianza

Chiluwa, I., \& Ifukor, P. (2015). War against our Children: Stance and Evaluation in \#BringBackOurGirls Campaign Discourse on Twitter and Facebook. Discourse and Society, 26(3), 267-296. doi:https://doi. org/10.1177/0957926514564735

Delgado, R. Ocampo, A. M., \& Robledo, C.M. (2008). La acción colectiva juvenil. Un modelo de análisis para su abordaje. Ponto-e-vírgula, (4), 196-216.

Enguix Grau, B. (2016). Activismo y Prácticas Digitales en la Construcción de una Esfera LGTB en España. Revista Dados, 59(3), 755-787. doi:https://doi.org/10.1590/00115258201691

Emejulu, A., \& McGregor. C. (2017). Towards a Radical Digital Citizenship in Digital Education. Critical Studies in Education, 1-17. doi:https://doi.org/10.1080/17508487.2016.1234494

Feixa, C., Juris, J. \& Pereira, I. (2012). La globalización alternativa y los novísimos movimientos sociales. Revista del centro de investigación de México, (37), 23-39.

Fernández-Planells, A. (2013). \#acampadabcn: el 15M desde Catalunya. In C. Feixa \& J. Nofre (Eds.), Generación indignada. Topías y utopías del 15M (pp. 87-116). Lleida: Milenio publicaciones.

Freire, P. y Shor, I. (2014). Miedo y osadía: La cotidianidad del docente que se arriesga a practicar una pedagogía transformadora. Buenos Aires: Siglo XXI Editores.

Fullam, J. (2017). Becoming a youth activist in the internet age: a case study on social media activism and identity development. International Journal of Qualitative Studies in Education, 30(4), 406-422. doi:https://doi. org/10.1080/09518398.2016.1250176

Garcés, M. (2010). Movimientos sociales y educación popular. La piragua, 32, 55-68.

Gibbons Pyles, D. (2017). A social semiotic mapping of voice in youth media: the pitch in youth video production. Learning, Media and Technology, 42(1), 8-27. doi:https://doi.org/10.1080/17439884.2016.1095209

Glenn, C. L. (2015). Activism or 'Slacktivism?': Digital Media and Organizing for Social Change. Communication Teacher, 29, 81-85. doi:https://doi.org/10.1080/17404622.2014.1003310

González-Lizarraga, M. G., Becerra-Traver, M. T., \& Yanez-Diaz, M.B. (2016). Cyberactivism: A new form of participation for University students. Comunicar, 24(46), 47-54. doi:https://doi.org/10.3916/C46-2016-05

Hardt, M., \& Negri, A. (2004). Multitud. Barcelona: Random House Mondadori S.A.

Heron-Hruby, A., \& Landon-Hays, M. (Eds.). (2014). Digital Networking for School Reform: The Online Grassroots Efforts of Parent and Teacher Activist. New York: Palgrave Macmillan. doi:https://doi. org/10.1057/9781137430748 
Irving, C. J., \& English, L.M. (2011). Community in Cyberspace: Gender, Social Movement Learning, and the Internet. Adult Education Quarterly, 61(3), 262-278. doi:https://doi.org/10.1177/0741713610380448

Juris, J. (2008). Performing Politics: Image, Embodiment, and Affective Solidarity during anti-Corporate Globalization Protests. Ethnography, 9(1), 61-97. doi:https://doi.org/10.1177/1466138108088949

Juris, J. (2012). Reflections on \#Occupy Everywhere: Social Media, Public Space, and Emerging Logics of Aggregation. American Ethnologist, 39(2), 259-279. doi:https://doi.org/10.1111/j.1548-1425.2012.01362.x

Khoury-Machool, M. (2007). Palestinian Youth and Political Activism: the Emerging Internet Culture and New Modes of Resistance. Policy Futures in Education, 5(1) 17-36. doi:https://doi.org/10.2304/pfie.2007.5.1.17

Knibbs, K. (2013). Slactivists, unite! Social media campaigns aren't just feel-good back patting. Retrieved from: https://goo.gl/a8dLKN

Knorr-Cetina, K. (2001). Objectual practice. In T. Schatzki, K. Knorr-Cetina \& E. Savigny (Eds.), The Practice Turn in Contemporary Theory (pp. 184-197). London and New York: Routledge.

LaRiviere, K., Snider, J., Stromberg, A., \& O'Meara, K. (2012). Protest: Critical Lessons of Using Digital Media for Social Change. About Campus, 17(3), 10-17. doi:https://doi.org/10.1002/abc.21081

Linder, Ch., Myers, J.S., Riggle, C., \& Lacy, M. (2016). From Margins to Mainstream: Social Media as a Tool for Campus Sexual Violence Activism. Journal of Diversity in Higher Education, 9(3), 231-244. doi:https://doi. org/10.1037/dhe0000038

McAdam, D., McCarthy, J. \& Zald, M. (1999). Oportunidades, estructuras de movilización y procesos enmarcadores: hacia una perspectiva sintética y comparada de los movimientos sociales. In: D. McAdam, J. McCarthy \& M. Zald (comps.), Movimientos Sociales: perspectivas comparadas (pp. 21-46). Madrid: Istmo.

Melucci, A. (1999). Acción colectiva, vida cotidiana y democracia. México: El Colegio de México-Centro de Estudios Sociológicos.

Metzger, M. W., Erete, S.L., Barton, D. L. Desler, M.K., \& Lewis, D.A. (2015). The new political voice of young Americans: Online engagement and civic development among first- year college students. Education, Citizenship and Social Justice, 10(1), 55-66. doi:https://doi.org/10.1177/1746197914558398

Mills, A., Schechter, S., Lederer, S., \& Naeher, R. (2011). Global Stories of Citizenship: Oral History as Historical Inquiry and Civic Engagement. The Oral History Review, 38(1), 34-62. doi:https://doi.org/10.1093/ohr/ ohr042

Osses, S., Sánchez, I., \& Ibáñez, F. (2006). Investigación cualitativa en educación. Hacia la generación de teoría a través del proceso analítico. Estudios Pedagógicos, 32(1), 119-133.

Pearson, E., Tindle, H., Ferguson, M., \& Litchfield, C. (2016). Can We Tweet, Post, and Share Our Way to a More Sustainable Society? A Review of the Current Contributions and Future Potential of \#Social media for sustaintability. Annual Review of Environment and Resources, 41, 363:397. doi:https://doi.org/10.1146/ annurev-environ-110615-090000

Peña, P., Rodríguez, R, \& Sáez, C. (2016). Student Movement in Chile, Situated Learning and Digital Activism. Commitment, Social Change and Technological Uses in Teenagers. OBETS, 11(1), 287-310. doi:https://doi. org/10.14198/OBETS2016.11.1.11

Rueda, R. (2004). Tecnocultura y sujeto cyborg: esbozos de una tecnopolítica educativa. Nómadas, $21,70-81$.

Share, R. A., \& Shayne, J. (2008). Youth-Adult Partnership in Community Organizing: A Case Study of the My Voice Counts! Campaign. Journal of Community Practice 14 (4): 113-127. doi:https://doi.org/10.1300/ J125v14n04_07

Schatzki, T. (2001). Introduction: practice theory. T. Schatzki, K. Knorr-Cetina \& E. Savigny (Eds.), The Practice Turn in Contemporary Theory (pp. 10-23). London and New York: Routledge.

Suaza, L. M. (2013). Hackeando al patriarcado: metáforas y prácticas sociales de mujeres con tecnologías. En R. Rueda, L. Ramírez y A. Fonseca (eds.), Ciberciudadanías, cultura política y creatividad social (pp. 145-197). Bogotá: Universidad Pedagógica Nacional: 145-197.

Tarrow, S. (1997). El poder en movimiento. Madrid: Alianza editorial.

Tilly, Ch. (1995). Lo movimientos sociales como agrupaciones históricamente específicas de actuaciones políticas. Sociológica, 28, 1-18.

Theocharis, Y. (2012). Cuts, Tweets, Solidarity and Mobilisation: How the Internet Shaped the Student Occupations. Parliamentary Affairs, 65, 162-194. doi:https://doi.org/10.1093/pa/gsr049

Touraine, A. (1987). El regreso del actor. Buenos Aires: Editorial Eudeba.

Touraine, A. (1997) ¿Podremos vivir juntos? México D.F.: Fondo de Cultura Económica.

Tufekci, Z. (2017). Twitter and Tear Gas. The Power and Fragility of Networked Protest. New Haven and London: Yale University Press

Urresti, M. (2008). Ciberculturas juveniles. Buenos Aires: La Crujía. 
Valenzuela, S. (2013). Unpacking the Use of Social Media for Protest Behavior: The Roles of Information, Opinion, Expression, and Activism. American Behavioral Scientist, 57(7), 920-942. doi:https://doi. org/10.1177/0002764213479375

Vivitsou, M., \& Viitanen, K. (2015). The pedagogies of the future: through young people's eyes in storytelling experiences with the digital in Finland and Greece. In S. Zlitni \& F. Lienard (Eds.), Electronic Communication: Political, Social and Educational Uses (pp.123-141). Bern: Peter Lang.

Weeks, P. (1999). Cyber-activism: World Wildlife Fund's Campaign to Save the Tiger. Culture y Agriculture, 21(3), 19-30. doi:https://doi.org/10.1525/cag.1999.21.3.19 